\title{
HOW ICT TEACHERS FEEL ABOUT TEACHING: A COMPARATIVE STUDY BETWEEN GREECE AND INDONESIA
}

\author{
Efrosyni-Alkisti Paraskevopoulou-Kollia ${ }^{1}$, \\ Nuning Kurniasih", \\ Christos-Apostolos Michalakopoulos ${ }^{3 \mathrm{i}}$ \\ ${ }^{1}$ Adjunct Assistant Professor, \\ University of Thessaly Department of \\ Computer Science and Biomedical Informatics, \\ Papasiopoulou 2-4, 35131, Lamia, \\ Greece \\ ${ }^{2}$ Library and Information Science Program, \\ Faculty of Communication Science, \\ Universitas Padjadjaran, Bandung, \\ Indonesia \\ ${ }^{3}$ MSc Student, \\ University of Thessaly Department of \\ Computer Science and Biomedical Informatics, \\ Papasiopoulou 2-4, 35131, Lamia, \\ Greece
}

\begin{abstract}
:
The issue of Computer Science entering schools first appeared during the '60s. The first academic Computer Science Department was founded during this decade at Purdue University and was followed by a second one at Stanford University. As far as the other levels of educational systems are concerned the wide introduction of computers into schools started during the '80s. This paper refers to a comparative small scale qualitative research that took place between two countries: Greece and Indonesia. It compares Greek and Indonesian Computer Science teachers' views on whether the Computer Science (or ICT or Computing or Informatics) course improves students' lives and could in general assist in teaching. Both Greece and Indonesia have included the course of Information and Communication(s) Technologies (ICT) in the curricula of their primary and secondary education levels. Data were collected through interviews (semi-structured and e-mail ones). We interviewed eleven (11) Greek and twenty (20) Indonesian Computer Science (or ICT or Computing or Informatics) teachers. For each country we carefully studied participants' answers, we categorized and analyzed them in order to obtain reliable results. Then we compared the two countries' results so as to find similarities and differences between them. After this comparison we drew the conclusion that the points
\end{abstract}

\footnotetext{
i Correspondence: email frini@uth.gr, nuning.kurniasih@unpad.ac.id, michalakopouloschristos@gmail.com
} 
of view of teachers coming from the two aforementioned countries are almost the same. Participants declared that they see teaching as a positive procedure and that they also consider ICT (or Computer Science or Computing or Informatics) course as important for their pupils'/students' lives.

Keywords: computer science, ICT, teachers, teaching, interviews

\section{Introduction}

During the 1960s Computer Science started emerging as a distinguished science and the term was first introduced by George Forsythe. Knuth notes about him that in 1961 he integrated the term CS in his paper entitled 'Engineering Students Must Learn both Computing and Mathematics' (Forsythe, 1961). More precisely he wrote:

"[Computers] are developing so rapidly that even computer scientists cannot keep up with them. It must be bewildering to most mathematicians and engineers...In spite of the diversity of the applications, the methods of attacking the difficult problems with computers show a great unity, and the name of Computer Sciences is being attached to the discipline as it emerges" (Forsythe, 1961, p. 177, in Knuth, 1972, p. 722).

"Computer science as a field deals with the theoretical foundation and the nature of information, algorithms and calculation, as well as with their technological application in the context of automated computer systems: their specification, design and implementation" (see also Zins, 2007; Buchanan, Aycock, Dexter, Dittrich \& Hvizdak, 2011; Comer et al., 1989, in Paraskevopoulou-Kollia et al., 2018).

As regards its presence as an educational subject, it all began during the '60s. The first academic Computer Science Department was founded in 1962 at Purdue University and the second one in 1965 at Stanford University (https://cs.stanford.edu/about/department-overview, 09.04.2020). At the same year the first Ph.D. in Computer Science was awarded to Richard Wexelblat from University of Pennsylvania (https://www.cis.upenn.edu/history/ 09.04.2020) and in University of Belgrade was composed a robotic hand (see also http://www.research.lancs.ac.uk/portal/en/publications/computer-science-cs-orinformation-and-communication-technologies-ict(0480a0e3-edc1-4b72-a2da244f2a31d883).html, 09.04.2020; Passey, 2017).

In 1964 appeared supercomputers, which are attributed to Seymour Cray (see also Roland, Shiman, \& Aspray, 2002) and great names, such as Noam Chomsky and Michael Rabin started an important work on Computer science field. During the '70s, well-known names, such as Edgar F. Codd (databases), Ken Thompson and Dennis Ritchie (Unix operating system), Dennis Ritchie and Brian Kernighan (C programming language), John Cocke (the first RISC architecture in IBM's) are to be found among computer scientists. 
During the '80s, the first personal computer was constructed (Steve Wozniak and Steve Jobs, Apple Computers) and from the '90s onwards computers became smaller and started entering our everyday life, apparently our educational systems and the daily school life as well.

With regard to other levels of education, in 1965 Elementary and Secondary Education Act was intended to finance schools for the purchase of technological material and around ten years later, Apple donated PCs to schools (https://web.csulb.edu/ murdock/histofcs.html, 08.04.2020), but the wide introduction of computers into schools occurred during the '80s (see Tatnall \& Davey, 2014, in Passey, 2017).

It is well known that a debate over the definition of Computer science has existed for many years and the problem becomes more complicated when the term is translated into other languages worldwide and especially when it is included in the various educational systems (see also McGuffee, 2000). Computer science, though, has to be taught in its unity, regardless of the way it is used (or pronounced) in the frame of each educational system.

Educators and especially those who teach Computing (or ICT or IT or Computer science $^{\mathrm{ii}}$ ) in specific educational systems are required to have some qualifications. They must possess special knowledge and collective abilities (see also Cornu, 2013; Loewenberg Ball, Thames, \& Phelps, 2008) for being able to operate effectively within the in-class environment and incorporate technology into most of their vital praxis. TPACK (Technological Pedagogical Content Knowledge) is a term that derived from the initiative of Matthew Koehler and Punya Mishra to add technology to the Lee Shulman's Pedagogical Content Knowledge (PCK). This model encapsulates what a teacher (especially ICT teacherii one may say) needs to know nowadays in order to successfully adjust technology to the curriculum as well as to the teaching strategies and represents the collaboration between Content knowledge (what has to be taught according to the curriculum), Pedagogical knowledge (a teachers' knowledge to choose among a variety of strategies and methods referring to in-class practicing so that the pupils/students can actually learn) and Technology knowledge (what educators know about technology and how they could harmonize it with the curriculum). "The TP ACK framework emphasizes on how the connections among teachers' understanding of content, pedagogy and technology interact with each other to produce effective teaching" (Koehler, et al., 2014, p. 101).

\subsection{ICT: how is taught in Greece}

In the light of our personal experience but mainly on the basis of Computer Science Curriculum of 1997 and Computer Science Curriculum of 2003 can be concluded that the course of Information and Communications Technologies (or Computer Science or

\footnotetext{
ii From now on in text we may use each one of these terms occasionally meaning the exact same course/lesson that is taught.

iii In text we may also use the term 'educator' and 'educators'.
} 
Computing or Informatics) in Greece is included in all levels of education (Ministry of Education, 1997, 2003).

ICT (or Computer science or Computing or Informatics, depending on the country and the translation followed (see also Passey, 2017) was inaugurated into the Greek educational system in Technical-Vocational High schools around the mid-1980s, which incorporated a programming course (Mpratisis, 2013; Mpratisis et al., 2012; Charpantidou \& Trachanopoulou, 2012). In 1992 the course was imported into Junior High schools (Gymnasium) as a separate course and finally via Computer Science Curriculum of 1997-1998 it was also introduced into General High schools (Mpratisis, 2013; Mpratisis et al., 2012). The 1997 Computer Science Curriculum stated the following: "... the elective courses with the title "Informatics Applications" and "Computer Applications" are included in the schedule of the 1st / 2nd / 3rd grades respectively of the General High school..." (Ministry of Education, 1997), while the compulsory courses "Development of Applications in Programming Environment" and "Computer Systems Technology and Operating Systems" as well as the elective courses "Multimedia-Networks", "Software Applications", "Computer Applications" were included in the cycle of Informatics and Services of the Technological Direction of the High school (Ministry of Education, 1997). Regarding primary education the ICT course was formally first imported by virtue of 2003 Curriculum (Plati, Mpellou \& Mikropoulos, 2012; Ministry of Education, 2003).

To make the long story short, it can be said that the purpose of importing this course into the Primary school is to motivate pupils/students to know the PC and gain comprehensive understanding of its functions while developing broader critical thinking and social behavior skills (Ministry of Education, 2003, 2016). At the Junior High school (Gymnasium) the aim of introducing this lesson is that students should deal with ICT, learn how to fully use a PC and then solve various problems (Ministry of Education, 2003, 2017). Finally, in High school (Lyceum), beyond knowing in depth Computer Science, the target of incorporating this course is that the students can also learn a programming language and develop analytical and synthetic thinking (Ministry of Education, 2014a, 2014b, 1997).

In primary education, ICT is taught one hour per week. In secondary education and more specifically in Junior High school (Gymnasium), ICT -in this level it is literally called Computer Science- is taught in all three (3) grades one hour per week. In the General High school (Lyceum), in the first grade, Informatics is an elective course and is taught two (2) hours per week, in the second grade it is compulsory / general course and is taught one (1) hour per week and in the third year of General High school (Lyceum) it is a "direction" course, leading to PanHellenic exams by June in order to enter University and is taught seven (7) hours per week.

\subsection{ICT: how is taught in Indonesia}

In Indonesia, subjects of information and communication technology (ICT) are given already at the elementary school, but also at the junior high school and the senior high school level. ICT subject was included at the 2006 curriculum, but it was removed from 
the 2013 curriculum. ICT teachers protested against this decision. The teachers argue that learning at the 21st century requires ICT as the basis for students' ability to master information literacy (Kusumah, 2013). Meanwhile, the Ministry of Education and Culture of the Republic of Indonesia (Kemendikbud) argued that in the industrial era 4.0, where generation $Z$ has used ICT in their daily lives, ICT no longer needs to be a separate subject, but must be integrated in all subjects. However, in 2018 the Ministry of Education and Culture stated that in 2019 ICT will re-enter the curriculum as a subject with a different concept. One of the differences can be identified at the use of the term Informatics instead of the term ICT subjects used before (Bona, 2018).

In the Guidelines for Implementing Informatics Subjects, it is stated that informatics is a discipline that seeks to understand and explore the environment around us related to the study, design, and implementation of computer systems and understanding of the principles on which the design is based (Ministry of Education and Culture of the Republic of Indonesia, 2019). In line with this policy, the Ministry of Education and Culture also emphasizes the importance of the quality of teachers who have expertise in this field. An informatics teacher must have an educator certificate and graduate from an undergraduate program related to computing, have abilities in computational thinking, computer engineering, computer/ internet networks, data analysis, algorithms and programming, social impact of informatics and ICT (Ministry of Education and Culture of the Republic of Indonesia, 2019).

\section{Material and Methods}

This research is a qualitative research with a comparative approach. Case studies try to explore a phenomenon naturally. The purpose of the case study is to gain an in-depth understanding of the phenomenon in a real-world context (Crowe et al., 2011). This small-scale study was based on interviews with Greek and Indonesian ICT/Computer science/Computing/Informatics teachers, with a view of enquiring about their perspectives and feelings on teaching and whether teaching especially IT/Computing helps and enforces pupils/students in their daily life and in their life in general. This research was conducted in two countries, namely in Greece and in Indonesia.

Primary data in this study were obtained through interviews. We interviewed 11 teachers from Greece and 20 teachers from Indonesia. The total number of informants in this study was 31 teachers. They are all Computer Technology and Informatics teachers in schools.

\subsection{Greece}

More specifically, as regards Greece, semi-structured e-mail interviews were used as research tool. Interviews intrigue researchers who use them (see also Potter, \& Hepburn, 2005; Jacob, \& Furgerson, 2012) and become truly interesting as research goes on. In order for the data to be collected, we need to discuss with persons who have gained experience (see also Mahjebeen, 2017; Beverland, \& Farrelly, 2010) on our research issue and 
additionally would be fond of sharing this experience with us (see also Campbell, et al., 2010; Dennis, 2014). It is remarkable that "types of interviews are often as many as the sources to which one can refer to" (Cohen, Manion, \& Morrison, 2008, p. 454) and that we need at least two parts to conduct research (Chalikias, Manolesou, \& Lalou, 2015; Paraskevopoulou-Kollia, 2019).

E-mail (or online or electronic) interviews are divided into synchronous and asynchronous. The first ones occur in real-time online discussion (see skype, viber, etc.) (see also Challob, Bakar, \& Latif, 2016; O'Connor, Madge, Shaw, \& Wellens, 2008) and asynchronous are experienced in non-real-time (Janghorban, Roudsari, \& Taghipour, 2014). The use of computers in qualitative methodology facilitates and supports nowadays lifestyle and more specifically email interviews are considered as a natural and relatively accurate way of communication (Burns, 2010; Fritz \& Vandermause, 2018).

As far as e-mail interviewing is concerned, researchers have glorified the opportunity to gain access to participants who live all over the world (Meho, 2006; Dimond, Fiesler, DiSalvo, Pelc, \& Bruckman, 2012) at the time and place that is convenient to them (Fritz \& Vandermause, 2017, in Paraskevopoulou-Kollia, 2019). Literature also indicates that the researcher who chooses to adopt email (or electronic or online) interviews has also the opportunity to analyze interviewees' exact words (Ratislavová, \& Ratislav, 2014; Bowden, \& Galindo-Gonzalez, 2015) and among other important advantages, does not spend a lot -or anything- (Fontes \& O'Mahony, 2008).

\subsubsection{The sample}

Our Greek sample consists of 11 (eleven) primary and secondary ICT (or Computing) school teachers. We asked them two questions. The one was 'How do you feel about teaching in general?' and the other was 'Do you think Informatics as a lesson/course has improved and improves your pupils'/students' lives?'. To be more specific, either we sent them these questions via e-mail or they wrote a text in social media platforms expressing themselves about the above mentioned points and thus helping us with our research. Data gathering took place from December 2019 till February 2020. The not particularly large number of the people having participated in our research resulted from the conjuncture, since it was difficult to find more people to respond, especially after COVID19 appeared and people in Greece, as in other countries too, felt -at least- reeled.

Among teachers' answers can be grouped in three (3) different categories. For each one (positive response, negative response, neutral response) we used different colour or/and different sign, in order to be able to clearly classify the results. Moreover, we designed bar charts and pie charts for each category depending on participants' relevant answers. Last but not least, what needs to be mentioned is that all teachers who were interviewed accepted to be involved in the research. No hesitation appeared, as we knew most of them and they introduced us to some of their colleagues.

Some noteworthy points before proceeding further: at first, the results of this research cannot be generalized -due to the small sample-, but there are some interesting findings for the two countries, which in our opinion are worth being highlighted; 
secondly, the answers were in Greek and, to be sincere, we faced some difficulties regarding transferring and accurately translating the exact meaning of some words.

\subsection{Indonesia}

The twenty teachers that we interviewed from Indonesia come from West Java Province. More accurately, they are 18 Senior High School (SMA) as well as Vocational High School (SMK) teachers and 2 Junior High School (SMP) teachers.

We processed the results of the interview. We categorized each answer, then analyzed and interpreted it in order to produce conclusions.

\section{Results and Discussion}

\subsection{Evidence from Greece}

The research participants ivanswered the following two questions: A) How do you feel about teaching in general? and B) Do you think Informatics as a lesson/course has improved and improves your pupils'/students' lives?

By carefully examining the answers to question A, we divided them into three (3) categories: the category of positive answers, the category of negative answers and the category of neutral answers. As positive were those responses classified which exemplified a positive attitude of teachers towards education. As negative were ranked the teachers' responses that seemed to be more adverse to education. Finally, as neutral were interpreted those answers which represented the opinion that education can be neither positive nor negative.

The bar chart Figure 1 illustrates how participants' answers to Question A were distributed among the three (3) categories we distinguished. It is remarkable that nine (9) out of eleven (11) educators gave a positive answer.

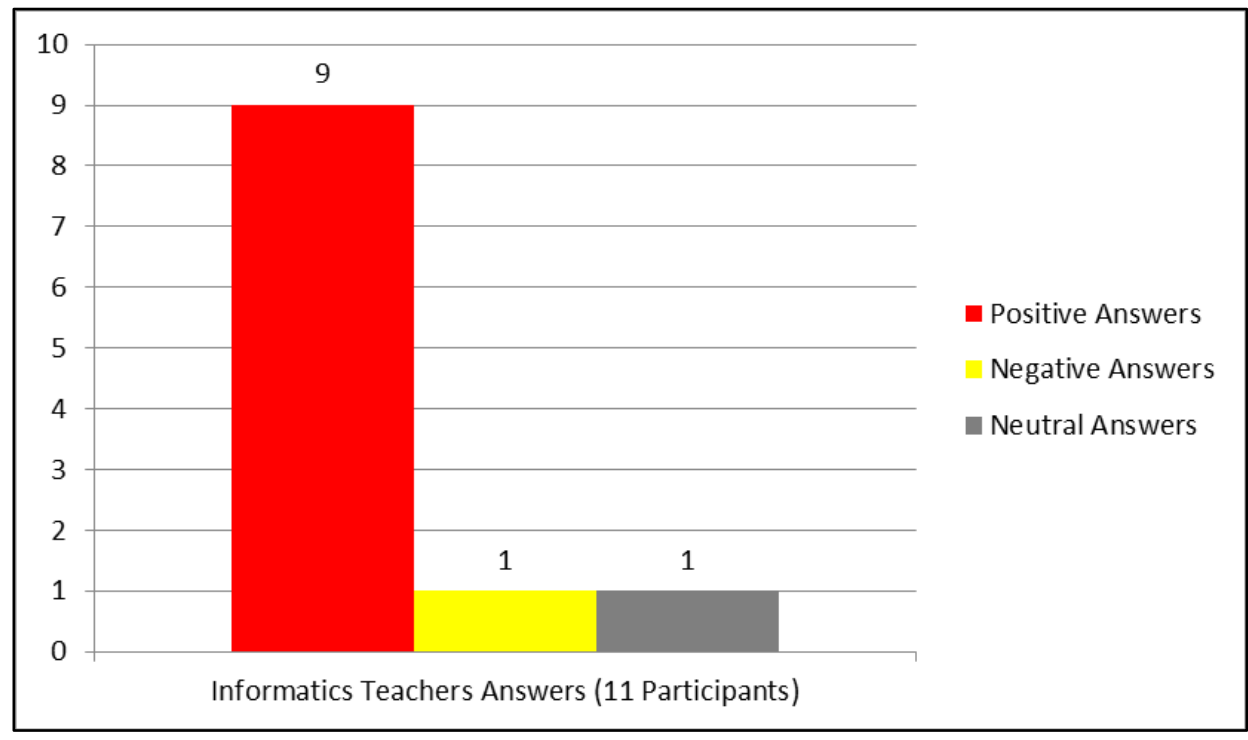

Figure 1: Participants' answers to question “How do you feel about teaching in general?".

iv From now on we will be using a code for each participant: $\mathrm{p} 1, \mathrm{p} 2$ and so on. 
Pointedly, participant 3 noted that "It is a lesson/course that gives you so many opportunities and freedom to handle it and teach it enjoyably."

Participant 4 replied that: "Teaching is great... when you manage to impart knowledge and skills to your pupils/students your feeling is unique... [...] The process is interesting and full of new experiences [...] Generally [...] when it comes to responsiveness and results, it rewards you."

Participant 8 declared that s/he feels "great love for teaching that aims to touch pupils'/students' hearts and mind", as well as "satisfaction and pride" and participant 11 shared with us that "Teaching was a childhood dream. As a pupil/student I enjoyed going up to the classroom and teaching my classmates! Now the dream has become a successful goal and I can only be happy. All of this joy and excitement is conveyed to my class and pupils/students!".

The exclamation marks indicate, if nothing else, her/his enthusiasm for the teaching process and what actually happening to her/him: 'childhood dream'. Teaching is described as a dream coming true due to the buoyant mood that it brings to teachers, due to its substantial-obvious results for pupils/students and for a lot of other optimistic reasons (see also Huhtala, 2015; Patton, \& Lesage, 2010; Ndirangu, 2008). At this point, it could be said that becoming a teacher is not always a conscious dream of life, but sometimes it originates from social role models and they characterize this profession. By the same token, in some cases it is not typified as profession, but as semi-profession (Price, \& Weatherby, 2018; Ingersoll, \& Collins, 2018; Lortie, 1975, Pyrgiotakis, 1992). Of course, this also depends on culture and customs each society has (MacBeath, 2012; Hotaman, 2010), but this assumption does not easily reverse the situation.

Research mentions that enthusiasm occurs in many educators (Metcalfe, \& Game, 2006; Wenström, Uusiautti, \& Määttä, 2018). Respectively, research refers to reward (see also Lavy, 2007), responsiveness and precisely pride, joy, happiness (Flores, \& Day, 2006) and freedom they may feel at their work (see also Hotaman, 2010; Hargreaves, 2005).

One (1) teacher gave a negative answer, indicating that $\mathrm{s} /$ he does not feel that ICT course/lesson is estimated from pupils/students:

"In this lesson/course and especially in High school, it is worth teaching only at 3rd grade. Pupils/Students take exams and that is why they take it seriously. [...] The other two High school lessons/courses are "child time". They don't want to learn anything, so... I don't care too much either". (p 2)

This answer clearly shows that this teacher does not have strong will to teach ICT due to her/his pupils'/students' reactions, a fact which undeniably has impact on her/his self-confidence and self-efficacy (see also Greenglass, Burke, \& Moore, 2003; Klassen, \& Chiu, 2010; Palmer, 2006).

Finally, one (1) teacher (participant 2) gave a neutral answer:

"It depends [on the level of the pupils/students, to the three schools I teach]". 
Summing up, research participants 1, 3, 4, 5, 6, 7, 8, 10, 11 responded positively, participant 2 responded negatively and participant 9 gave a neutral response. It is, also, worth accentuating that out of the nine (9) positive responses we noticed that only two (2) answers were clearly positive; those of participants 5 and 11 . Research participants 1 , $4,7,8,10$ gave a positive answer, their answers contained though elements of concern:

"I feel pleasure and satisfaction, but sometimes I feel insecure because there is no continuity in primary school because of the lack of a textbook" (p 1),

"Pleasantly, when the necessary teaching equipment exists (well-equipped laboratories) and pupils/students respond and participate in the learning process". ( $\mathrm{p} 7)$

Finally, participant 3 responded positively, but focused on teaching a lesson/course rather than teaching in general:

"It (the coursellesson) has no rigorous curriculum and exams. You can also link it to all other courses and sciences". ( $\mathrm{p} 3$ )

Studying the answers to question B, we found out that eight (8) out of the eleven (11) participants had the opinion that Informatics as a lesson/course improved pupils'/students' lives and three (3) argued that Informatics as a lesson/course did not improve pupils'/students' lives. Positive were the responses of research participants 1,4 , $5,6,7,8,9,11$ :

"Through informatics they (pupils/students) learn to harness the capabilities of computers to build digital material, useful for their present and future lives in the digital world. At the same time, however, and perhaps the most important of all is the development of computational and algorithmic thinking". ( $\mathrm{p} 4)$

"Digital literacy is necessary and interconnected with the modern age. [...] the Informatics course equips pupils/students with knowledge and critical thinking to handle information's overflow that the Internet generously offers". (p 6)

"Computer science as a taught lesson/course has helped my students to develop their creativity, imagination, analytical spirit, problem modeling skills, so that in a deductive way they are able to generalize the resolution of authentic computational problems and computational thinking skills". (p 8)

The responses of participants 2, 3, 10 were negative:

"If motives were given, such as a state Certificate, the job would be the most serious than all. Unfortunately, [...] Informatics courses have nothing to offer them". (p 2) 
"If pupils/students could know how useful it would be for their future -any kind of- job and their entertainment they would believe that this course is important. Now they feel that it offers them nothing...". (p 3)

"Unfortunately, no. The structure of the lesson/course is [...] based on technologies that are several years behind. As a result of the above, children do not learn useful things and therefore the computer science lesson/course does not help them in their daily lives". (p 10)

Going through bibliographical resources we may ascertain that it is a fact by now: pupils/students are actually helped from technology (see also Gurung, \& Rutledge, 2014), digital literacy is principal in their quotidian life (Martín, \& Tyner, 2012; Bawden, 2008) and problem-solving via computational thinking (constructing and deconstructing conceptualizations) makes them vigorous (see also Lye, \& Koh, 2014; Resnick, 2002).

Teachers work into a social frame and this affects the way they see themselves (Kolikant, 2011). Into that context they have to learn how to use ICT in classrooms. Kastis 2004 (in Birbili \& Papaoikonomou, 2016) mentions the really old procedure that has been followed regarding teachers' training on ICT (in Greece) and this procedure does not help teachers to become more effective or forceful (see also Kalogiannakis, 2010; Csernoch \& Biró, 2017). Computing teachers, in particular, may feel "overwhelmed and lacking in control over their teaching", due to the previously mentioned social ground and (due to) "the rapid evolution of Computing and, subsequently, their lack of knowledge of its current trends and didactics, as well as the perceived student culture about Computing as being all about games and surfing the Internet" (Kordaki, 2013, p. 150).

But bear in mind that a Computing teacher offers motivations to her/his pupils/students (see also Jenkins, 2001) and finally, "... when students saw the value of learning ICT for themselves, this may made ICT teachers feel useful and satisfied" (Deryakulu, Buyukozturk, Karadeniz, \& Olkun, 2008, p. 483); it functions vice versa. Taking this further, ICT teachers' self-efficacy is closely connected to their pupils'/students' way of viewing Computing and its teaching procedures and especially the way it may affect the following days. Summing up, Greek teachers' opinions are compatible enough with what worldwide occurs.

The bar chart Figure 2 shows the number of positive answers and the number of negative answers given by participants. 


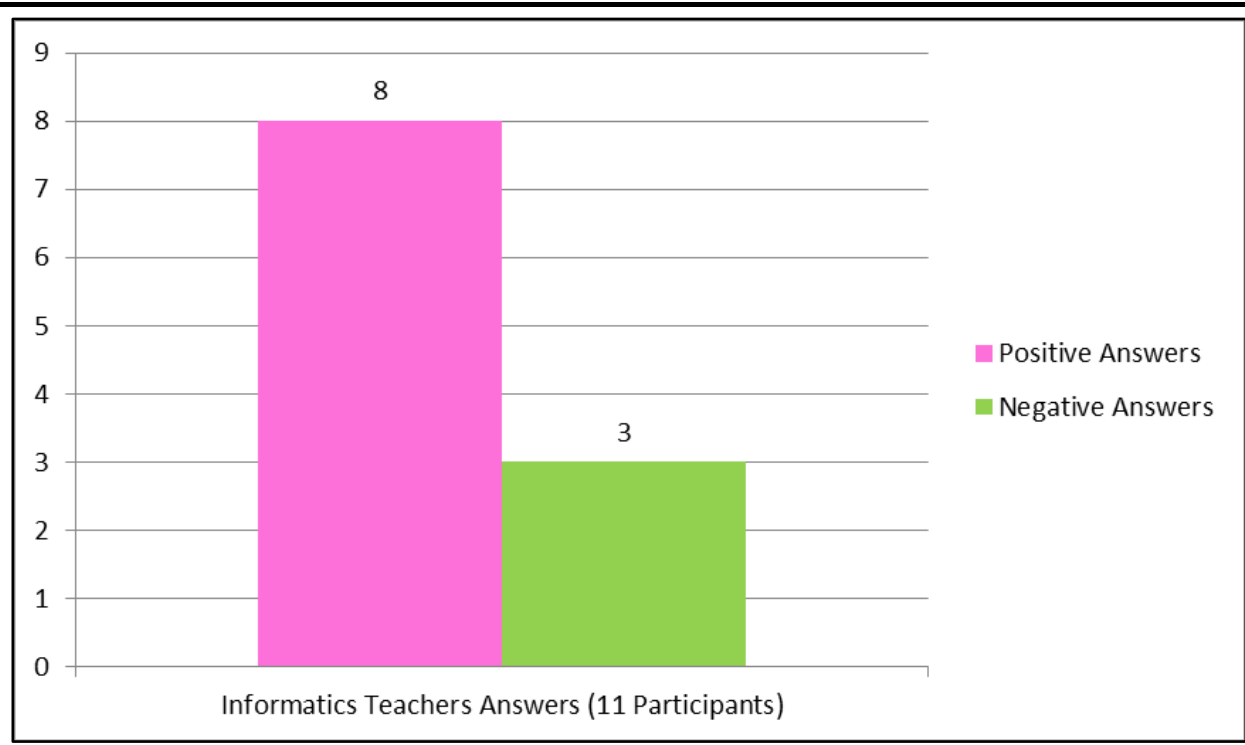

Figure 2: The number of positive answers and the number of negative answers given by participants

To be more specific, participants 1,4 , and 5 have the point of view that via Informatics (as a lesson), pupils/students stop viewing a computer only as a fun device, but they also consider it as a useful tool for their daily lives (see also Arpaci, 2016; Corrin, Lockyer, \& Bennett, 2010; Kubiatko, Haláková, Nagyová \& Nagy, 2011). Participants 4, 5, 6 and 8 reported that the Informatics course/lesson reinforces pupils'/students' critical, computational and algorithmic thinking. With all reservations, we can say that all positive answers hold the view that ICT helps pupils/students to become familiar with the modern/digital 'age' we live in (see also Bowers \& Berland, 2013; Claro et al., 2012; Wang, Hsu, Campbell, Coster, \& Longhurst, 2014).

\subsection{Evidence from Indonesia}

\subsubsection{The Feelings of Indonesian Teachers on Teaching Computer Technology and Informatics}

According to the interview results, 19 out of 20 (95\%) teachers stated that they feel happy, comfortable, very confident and appropriate for teaching Computer Technology and Informatics; they have fun during this teaching process and find it really enjoyable. The report showed that $95 \%$ of the informants in this study have positive feelings about their work or profession. On the contrary, one (5\%) teacher stated that there is nothing special in it, which could be interpreted as a neutral response. One direct statement of a very satisfied with the procedure of teaching ICT informant is as follows:

"I think it's fun, because with ICT subjects at school students' knowledge can increase, as students can follow the development of ICT every second, so we have the opportunity to explore more about ICT. It makes me obsessed with it. I always get new ideas and even have more knowledge than other teachers" (Transcript of the interview with Informant 
Number 18, the interview was conducted in Indonesian and translated by us).

Positive feelings about work will influence success at work. There are several variables that create positive feelings or emotions, namely "positive beliefs, creativity, work involvement, positive coping, health, teamwork and collaboration, customer satisfaction, leadership, and performance" (Diener, Thapa \& Tay, 2020). Meanwhile, emotional syndrome is influenced by cognitive, psychosocial, motivational and subjective feelings (Poggi \& Germani, 2003).

In this study we found out several reasons which explain how these teachers have those positive feelings. The first reason is that the subjects they teach are in accordance with their educational background. The suitability for a specific field deriving from the relevant educational background fosters a person's confidence. The teachers feel that they understand well the subject matter they have to convey to their students. Some research results demonstrate how educational qualifications can contribute to a good performance (Aksoy, 1998; Bosupeng, 2017; Kalota, 2015; Ng \& Feldman, 2009).

The second reason is self-development, namely people's willingness to improve their knowledge and skills. According to informants, the development of information and communication technology is surprisingly rapid. Consequently, this provides teachers with the opportunity to learn something new quickly so that they can explore new ideas as well as obtain knowledge and skills very fast. Self-development is a very important process and prerequisite for employee career development, including teachers (Antonacopoulou, 2000; The Educational \& Training Foundation, 2014). For ICT teachers there are at least three skills that need to be developed: ICT skills and awareness, professional skills in ICT, and pedagogical skills (Inspectorate Evaluation Studies, 2008). However, the informants emphasized that the deficiencies of technological infrastructure in their schools were still an obstacle to achieving greater progress.

The third reason is the usefulness of the teaching material delivered. As informants argued, the subject of information and communication technology offers students the knowledge and skills needed in the industrial era 4.0. Through these subjects, students will better understand technology in general and more precisely, how technology can play a role in the learning process and can support various fields, how they can use technology in everyday life and as a result, students will gain the skills needed in the future. The informants hope technology can change the way of thinking and acting of young people so that they can make good use of it in their lives. Nevertheless, the teachers realize that some students can learn ICT first. This is a challenge for teachers to always update the latest knowledge and skills in the field of technology. Teacher readiness during/for teaching is the key to the quality of learning, especially if teachers manage to integrate the subject matter in their students' daily lives (Ghavifekr \& Rosdy, 2015). 


\subsubsection{Teacher's Opinion about the Role of Information Technology in Students' Daily} Lives

The results of interviews with 20 informants in West Java of Indonesia showed that all informants $(100 \%)$ believe that technology has a very important role for student life. The informants have the opinion that ICT is one of the competencies needed in the current era. They said that today all fields of life cannot be cut off from technology. Therefore, they argued that ICT subjects studied by students in school will have an impact on student life. A teacher gave the example that, for the Computer-Based National Exam (UNBK), students must know how to operate a computer and that this competency is gained through Computer Technology and Information subjects. The teachers also think that ICT provides easy access to information, social interactions, social transactions, etc. The following is one of the direct statements made by one of the informants at the interview:

"Very important. In this century, all actions cannot be dissociated from the role of information technology. Every type of science, every type of work is always closely related to information technology. Information technology makes it easier to complete a job, anytime, anywhere, any kind of work. Information technology is increasingly developing along with the times and its role is needed in life. If the subject of information technology is linked to the current lives of students, then it will have an important impact on them. Students will get used to completing a job with information technology, this is very useful for students' careers in the future" (Transcript of the interview with Informant Number 10, the interview was conducted in Indonesian and translated by us).

In the statement of one of the informants above can be remarked that in his opinion, ICT has an important role in students 'lives, where ICT can help them to complete a job quickly and provide them with knowledge and skills for their careers in the future. The informants stated that currently all companies need workers who have advanced capacities in the field of technology.

One of the highlights is that 5 out of $20(25 \%)$ informants stated that ICT provides the knowledge and skills needed in business or industry so students can build their own business, become entrepreneurs by utilizing technology. With regard to the students' careers in the future, another informant said that many of their students had successfully established start-ups and worked in IT companies with very high salaries. Thus, the informants argue strongly that ICT subjects should be included in the education curriculum. Especially now, we see that there is still a digital divide. One informant stated that she teaches in small cities where technology has not prevailed, it is very important though that basics of knowledge and skills about technology are conveyed to students. The following is a direct statement from one of our research informants:

"IT subjects are important and must be in the curriculum structure especially since I became a teacher in an area that is still less touched by technology. At least my students 
can operate MS. Office for their work that requires IT skills" (Transcript of the interview with Informant Number 3, the interview was conducted in Indonesian and translated by us).

From the statement of one of the informants above can be concluded that for students in small cities, where information technology facilities are inadequate, basic skills, such as Ms Office will be very useful for the students. However, informants also stressed that skills in ICT must go hand in hand with good behavior and strong faith so that ICT can be utilized appropriately.

Finally, the informants highlighted that when the COVID-19 epidemic hit the world, distance learning played an important role. With ICT skills at least a student can use e-learning, such as video conferences or other e-learning features.

Teachers' perceptions about the use of ICT in students' everyday lives are fundamental for developing learning materials (Lubin, 2016; Vanderlinde \& van Braak Johan, 2011). Teachers' perception about the usefulness of ICT in students' daily lives is a basis for developing learning material. The teachers make innovations to develop a curriculum that can be implemented in everyday life and create students who are able to compete in the global era.

\subsection{Comparing two countries' analysis}

Comparing teachers' answers to the first question, we have to remark that in a very high percentage the IT teachers of both countries have a positive attitude towards education. About $82 \%$ of Greek teachers and $95 \%$ of Indonesians demonstrate a positive attitude towards education. Nevertheless, there is a difference between the two countries. The positive attitude of Greek teachers is most often accompanied by concerns about the educational process and the ICT course itself, which does not seem to be the case regarding Indonesian teachers.

Comparing the analysis of the answers to the second question, we came to the conclusion that IT teachers in both countries consider the ICT course as important for their students' lives. However, there is a difference; Indonesian teachers are the most ardent supporters of this perspective, compared to the Greek ones, as the percentage of the sample that expressed this view reaches $100 \%$, while the percentage of Greeks who supported this view is about $73 \%$. In conclusion, we could claim that teachers' aspects from both countries in general converge.

\section{Conclusion}

The main purpose of this article was to investigate and mention any differences or similarities regarding Greek and Indonesian ICT teachers' points of view on two questions. The first one was 'How do you feel about teaching in general?' and the second one was 'Do you think Informatics as a lesson/course has improved and improves your pupils'/students' lives?'. 
"The fields of Computer Science and Information Technology are clearly distinct, yet so closely related to each other that it makes sense [...] to treat them as a single group and consider Computer Science and Information Technology professionals as members of the same profession, at least within the context of their functioning as teaching professionals" (Paraskevopoulou-Kollia et al., 2018, p. 41).

Regarding the above mentioned, technological progress is occurring at a frantic pace. Computers have undoubtedly become an integral part of our lives and the so-called social interaction web is almost attached to the web networks that compose the Internet (see also Brailovskaia \& Bierhoff, 2016; Desai \& Lele, 2017). This is one of the main reasons why it is important for children to be taught Computer Science (see also Webb, Davis, Bell, Katz, Reynolds, Chambers, \& Sysło, 2017; Guzdial, Kay, Norris, \& Soloway, 2019) from an early age, in order to be able to cope with the role of liable citizen of the small society in which they live, but also of the world around them.

Certain cultures include specific elements in every society (Sorokin, 2017; Pavlyshyn, Voronkova, Yakutina, \& Tesleva, 2019). The educational structure of each country differs from, but also resembles with this of many neighboring or distant countries. Certainly, though, the educational system and the way it is structured are influenced by the aforementioned culture of the place where they are 'born'. It is also sure that respectively to the specifics of a particular culture surrounding the educational structure of each place, it is natural that the teaching process (and learning) will be modified over time (see also Webb, 2006; Meirink, Meijer, Verloop, \& Bergen, 2009).

In Greece, Informatics as a subject taught at school was belatedly-compared to other countries- integrated in the various educational levels and once introduced, was observed the phenomenon of diverging views by the competent bodies about course's objectives or its usefulness (for this teaching hours change every year) (see also Paraskevopoulou-Kollia, 2015; Zadiropoulou, 2016).

Greek teachers, whom we asked, noted that teaching is rewards, pride, happiness and freedom (see also Muijs \& Reynolds, 2017) and that ICT course enhances their pupils'/students' lives -although there were few, specific answers reminding us that the course should be approached differently by pupils/students.

Indonesia ICT was in Curriculum, but was removed from it in 2013 just to re-enter Curriculum in 2019 in the light of the real importance of ICT and ICT teachers' empowerment on knowledge and skills.

It is a fact that teaching profession needs to be more connected to research regarding educational procedure and also to teachers' points of view on teaching practicing (see also Rey \& Gaussel, 2016; Valeeva \& Gafurov, 2017; Sonia, 2017), since teachers as professionals have many simultaneous tasks (see also Golden, 2018; Matewos, Marsh, McKibben, Sinatra, Le, \& Polikoff, 2019). Considering especially ICT (or Computer science or Computing or Informatics) teachers, among the usual tasks and roles of every teacher, they have additionally to think about the renewal of their knowledge and skills, which is persistently required, in order for them to feel adequate 
to cope with nowadays society's technological progress (see also Kallia \& Sentance, 2017; Cakir \& Yildirim, 2013).

Indonesian teachers stated that Computing and especially ICT (or IT) plays really an important role on pupils'/students' life, but also on their life, in general. Indonesian teachers responded that they feel happiness, joyfulness, comfortability, credence and faith on what they teach and most of them replied that they like their profession. All these positive feelings rely upon their educational and more particular scientific background, which is relevant to what they teach -and so it helps them to feel more confident- (see also De Smul, Heirweg, Van Keer, Devos, \& Vandevelde, 2018; Bressman, Winter, \& Efron, 2018), upon their self-development and the fact that the teaching material (they feel that it) is important (see also Grossman \& Thompson, 2008; Roth, Assor, KanatMaymon, \& Kaplan, 2007; Ljubojevic, Vaskovic, Stankovic, \& Vaskovic, 2014).

We would at last like to remind that our research cannot be generalized as it does not include large sample and has not covered all possible parameters and conditions related to the questions that participants answered (see also Mays \& Pope, 2020; Williams, 2000). However, it demonstrates some important facts concerning the two countries in terms of Informatics as a subject taught at school as well as teaching as a process and these points should be emphasized (see also Smith, 2018; Hromkovič \& Steffen, 2011). Furthermore, as Payne and Williams (2005, in Parker \& Northcott, 2016) pointed out, generalizing is trying to convince that a situation could be repeated in another place and at another time, but we should take a moment to just think that our societies are built from people acting exactly like that (claiming claims).

Concluding, as Osborne \& Hennessy (2003) mentioned, it is of great importance for pupils/students to develop practical skills; it plays significant role on their daily lives and undoubtedly helps them to comprehend the connection between the theoretical background of Computer Science and reality. Teachers are the coordinators and instructors of this whole procedure and when they feel fine considering their profession, everything flows effectively (see also Skaalvik \& Skaalvik, 2015; Isenbarger \& Zembylas, 2006; Van Veen \& Sleegers, 2006).

\section{Conflicts of Interest}

The authors declare that there is no conflict of interest.

\section{About the Authors}

Efrosyni-Alkisti Paraskevopoulou-Kollia is member of the teaching staff of University of Thessaly (School of Science), at undergraduate and postgraduate level. Her academic and research interests focus on Methods of teaching various scientific subjects, ICT in Education, Sociology of Education and Methodology of Educational Research. https://orcid.org/0000-0003-1317-4686 https://scholar.google.gr/citations?hl=el\&user=wz-ntUAAAAJ. 
Nuning Kurniasih is faculty member of Universitas Padjadjaran (Faculty of Communication Sciences) at the department of Library of Information Science. For more information please visit the links https://orcid.org/0000-0002-5146-1849, https://www.scopus.com/authid/detail.uri?authorId=57200989264.

Michalakopoulos Christos - Apostolos is a primary and secondary education Informatics teacher at Greek Ministry of Education. He is currently an MSc student at University of Thessaly in Department of Computer Science and Biomedical Informatics. For more information please visit the link https://orcid.org/0000-0001-8766-8588.

\section{References}

Aksoy, H. H. (1998). Relationship Between Education and Employment: How Do Employers Use Educational Indicators in Hiring? (Results from A Participatory Observation)*. In Educational Resources Information Center (ERIC). Ankara.

Antonacopoulou, E. P. (2000). Employee development through self-development in three retail banks. Personnel Review, 29(4), 491-508. https://doi.org/10.1108/00483480010296294

Arpaci, I. (2016). Understanding and predicting students' intention to use mobile cloud storage services. Computers in Human Behavior, 58, 150-157.

Bawden, D. (2008). Origins and concepts of digital literacy. Digital literacies: Concepts, policies and practices, 30(2008), 17-32.

Beverland, M. B., \& Farrelly, F. J. (2010). The quest for authenticity in consumption: Consumers' purposive choice of authentic cues to shape experienced outcomes. Journal of Consumer Research, 36(5), 838-856.

Birbili, M., \& Papaoikonomou, A. (2016). The effect of the degree of professional development on the teaching practices of English language teachers: empirical approach. Scientific Yearbook [I epidrasi tou vathmou epaggelmatikis anaptyxis stis didaktikes praktikes ton didaskonton agglikis glossas: empeiriki proseggisi]. Scientific Yearbook, Department of Nursery teachers, University of Ioannina, 9(2), 45-77. doi: https://doi.org/10.12681/jret.10197 (15.04.2020)

Bona, F. M. (2018). Sempat Dihapus, TIK Kembali Diajarkan pada $2019=$ Once erased, ICT will re-enter the curriculum in 2019. Www.Beritasatu.Com. Retrieved from https://www.beritasatu.com/nasional/508445/sempat-dihapus-tik-kembalidiajarkan-pada-2019

Bosupeng, M. (2017). How Relevant Are Academic Degrees in the Workplace? In MPRA Paper No. 77914. Retrieved from https://mpra.ub.uni-muenchen.de/77914/

Bowden, C., \& Galindo-Gonzalez, S. (2015). Interviewing when you're not face-to-face: The use of email interviews in a phenomenological study. International Journal of Doctoral Studies, 10(12), 79-92.

Bowers, A. J., \& Berland, M. (2013). Does recreational computer use affect high school achievement?. Educational Technology Research and Development, 61(1), 52. 
Brailovskaia, J., \& Bierhoff, H. W. (2016). Cross-cultural narcissism on Facebook: Relationship between self-presentation, social interaction and the open and covert narcissism on a social networking site in Germany and Russia. Computers in Human Behavior, 55, 251-257.

Bressman, S., Winter, J. S., \& Efron, S. E. (2018). Next generation mentoring: Supporting teachers beyond induction. Teaching and teacher education, 73, 162-170.

Buchanan, E., Aycock, J., Dexter, S., Dittrich, D., \& Hvizdak, E. (2011). Computer science security research and human subjects: Emerging considerations for research ethics boards. Journal of Empirical Research on Human Research Ethics, 6(2), 71-83.

Burns, E. (2010). Developing email interview practices in qualitative research. Sociological research online, 15(4), 24-35.

Cakir, R., \& Yildirim, S. (2013). ICT teachers' professional growth viewed in terms of perceptions about teaching and competencies. Journal of Information Technology Education, 12, 221-237.

Campbell, R., Adams, A. E., Wasco, S. M., Ahrens, C. E., \& Sefl, T. (2010). “What has it been like for you to talk with me today?": The impact of participating in interview research on rape survivors. Violence against women, 16(1), 60-83.

Chalikias, M., Manolesou, A., \& Lalou, P. (2015). Research methodology and introduction to statistical data analysis with IBM SPSS statistics. Association of Greek Academic Libraries.

Challob, A. A. I., Bakar, N. A., \& Latif, H. (2016). Collaborative Blended Learning Writing Environment: Effects on EFL Students' Writing Apprehension and Writing Performance. English Language Teaching, 9(6), 229-241.

Charpantidou, Z., \& Trachanopoulou, I. (2012). Using Logo to teach repetition structure compared to using LEGO Mindstorms: a case study with High school students. [I chrisi tis LOGO gia ti didaskalia tis domis epanalipsis se sigkrisi me ti chrisi ton LEGO Mindstorms : meleti periptosis me mathites Gymnasiou]. in Greek. Paper presented at the 60 Panhellenic Conference on "Informatics Didactic", Florina. https://didinfo2012.web.uowm.gr/3-41-46.pdf (01.04.2020)

Claro, M., Preiss, D. D., San MartíN, E., Jara, I., Hinostroza, J. E., Valenzuela, S., \& Nussbaum, M. (2012). Assessment of 21st century ICT skills in Chile: Test design and results from high school level students. Computers \& Education, 59(3), 10481053.

Cohen, L., Manion, L., \& Morrison, K. (2008). Research methods in education.

Corrin, L., Lockyer, L., \& Bennett, S. (2010). Technological diversity: An investigation of students' technology use in everyday life and academic study. Learning, Media and Technology, 35(4), 392-396.

Cornu, B. (2013). Networking and collective intelligence for teachers and learners. In World Yearbook of Education 2004 (pp. 54-59). Routledge.

Crowe, S., Cresswell, K., Robertson, A., Huby, G., Avery, A., \& Sheikh, A. (2011). The case study approach. Medical Research Methodology, 11(100), 1471-2288. https://doi.org/10.1177/108056999305600409 
Csernoch, M., \& Biró, P. (2017). Teaching methods are erroneous: approaches which lead to erroneous end-user computing. arXiv preprint arXiv:1704.01130.

Dennis, B. K. (2014). Understanding participant experiences: Reflections of a novice research participant. International Journal of Qualitative Methods, 13(1), 395-410.

Deryakulu, D., Buyukozturk, S., Karadeniz, S., \& Olkun, S. (2008). Satisfying and frustrating aspects of ICT teaching: A comparison based on self-efficacy. International Journal of Social, Management, Economics and Business Engineering, 2(10), 481-484.

Desai, S. P., \& Lele, V. (2017). Correlating internet, social networks and workplace-A case of Generation Z students. Journal of Commerce and Management Thought, 8(4), 802815.

De Smul, M., Heirweg, S., Van Keer, H., Devos, G., \& Vandevelde, S. (2018). How competent do teachers feel instructing self-regulated learning strategies? Development and validation of the teacher self-efficacy scale to implement selfregulated learning. Teaching and Teacher Education, 71, 214-225.

Diener, E., Thapa, S., \& Tay, L. (2020). Annual Review of Organizational Psychology and Organizational Behavior Positive Emotions at Work. Annu. Rev. Organ. Psychol. Organ. Behav. 2020, Vol. 7, pp. 451-477. https://doi.org/10.1146/annurev-orgpsych$\underline{012119}$

Dimond, J. P., Fiesler, C., DiSalvo, B., Pelc, J., \& Bruckman, A. S. (2012, October). Qualitative data collection technologies: A comparison of instant messaging, email, and phone. In Proceedings of the 17th ACM international conference on Supporting group work (pp. 277-280).

Flores, M. A., \& Day, C. (2006). Contexts which shape and reshape new teachers' identities: A multi-perspective study. Teaching and teacher education, 22(2), 219-232.

Fontes, T. O., \& O’Mahony, M. (2008). In-depth interviewing by Instant Messaging. Social Research Update, 53(2), 1-4.

Forsythe, G. E. (1961). Engineering students must learn both computing and mathematics. Journal of Engineering Education, 52(3), 177-188.

Fritz, R. L., \& Vandermause, R. (2018). Data collection via in-depth email interviewing: Lessons from the field. Qualitative Health Research, 28(10), 1640-1649.

Ghavifekr, S., \& Rosdy, W. A. W. (2015). Teaching and Learning with Technology: Effectiveness of ICT Integration in Schools. International Journal of Research in Education and Science, 1(2), 175. https://doi.org/10.21890/ijres.23596

Golden, N. A. (2018). Narrating neoliberalism: Alternative education teachers' conceptions of their changing roles. Teaching Education, 29(1), 1-16.

Greenglass, E. R., Burke, R. J., \& Moore, K. A. (2003). Reactions to increased workload: Effects on professional efficacy of nurses. Applied psychology, 52(4), 580-597.

Grossman, P., \& Thompson, C. (2008). Learning from curriculum materials: Scaffolds for new teachers?. Teaching and teacher education, 24(8), 2014-2026.

Gurung, B., \& Rutledge, D. (2014). Digital learners and the overlapping of their personal and educational digital engagement. Computers $\mathcal{E}$ Education, 77, 91-100. 
Guzdial, M., Kay, A., Norris, C., \& Soloway, E. (2019). Computational thinking should just be good thinking. Communications of the ACM, 62(11), 28-30.

Hargreaves, A. (2005). The emotions of teaching and educational change. In Extending educational change (pp. 278-295). Springer, Dordrecht.

Hotaman, D. (2010). The teaching profession: knowledge of subject matter, teaching skills and personality traits. Procedia-Social and Behavioral Sciences, 2(2), 1416-1420.

Hromkovič, J., \& Steffen, B. (2011, October). Why teaching informatics in schools is as important as teaching mathematics and natural sciences. In International Conference on Informatics in Schools: Situation, Evolution, and Perspectives (pp. 21-30). Springer, Berlin, Heidelberg.

Huhtala, A. (2015). Becoming a Language Teacher: A dream come true or a source of anxiety?. Apples: journal of applied language studies.

Ingersoll, R. M. \& Collins, G. J. (2018). The Status of Teaching as a Profession. In J. Ballantine, J. Spade, and J. Stuber (Eds.), Schools and Society: A Sociological Approach to Education (p. 199-213) 6th Ed. CA: Pine Forge Press/Sage Publications.

Inspectorate Evaluation Studies. (2008). ICT in Schools. Retrieved from https://www.education.ie/en/Publications/Inspection-Reports-

Publications/Evaluation-Reports-Guidelines/ICT-in-Schools-InspectorateEvaluation-Studies.pdf

Isenbarger, L., \& Zembylas, M. (2006). The emotional labour of caring in teaching. Teaching and teacher education, 22(1), 120-134.

Jacob, S. A., \& Furgerson, S. P. (2012). Writing interview protocols and conducting interviews: Tips for students new to the field of qualitative research. Qualitative Report, 17, 6.

Janghorban, R., Roudsari, R. L., \& Taghipour, A. (2014). Skype interviewing: The new generation of online synchronous interview in qualitative research. International journal of qualitative studies on health and well-being, 9(1), 24152.

Jenkins, T. (2001, July). Teaching programming-a journey from teacher to motivator. In The 2nd Annual Conference of the LSTN Center for Information and Computer Science.

Kallia, M., \& Sentance, S. (2017, November). Computing Teachers' Perspectives on Threshold Concepts: Functions and Procedural Abstraction. In Proceedings of the 12th Workshop on Primary and Secondary Computing Education (pp. 15-24).

Kalogiannakis (2010). Training with ICT for ICT from the trainee's perspective. A local ICT teacher training experience. Educ Inf Technol (2010) 15:3-17. DOI 10.1007/s10639-008-9079-3 (15.04.2020)

Kalota, F. (2015). Applications of big data in education. International Journal of Social, Behavioral, Educational, Economic, Business and Industrial Engineering, 9(5), 16051612. Retrieved from file:///E:/Doctorate/Artikel 1 Scopus S3/Data Artikel1 Big Data/BigData

Management/38dbfcb1ad2f540720d85a5c69eab8de8f0fc541b3121b1fd862a7b6fedc bb92.PDF 
Klassen, R. M., \& Chiu, M. M. (2010). Effects on teachers' self-efficacy and job satisfaction: Teacher gender, years of experience, and job stress. Journal of educational Psychology, 102(3), 741.

Knuth, D. E. (1972). George Forsythe and the development of computer science. Communications of the ACM, 15(8), 721-726.

Koehler, M. J., Mishra, P., Kereluik, K., Shin, T. S., \& Graham, C. R. (2014). The technological pedagogical content knowledge framework. In Handbook of research on educational communications and technology (pp. 101-111). Springer, New York, NY.

Kolikant, Y. B. D. (2011). Computer science education as a cultural encounter: a sociocultural framework for articulating teaching difficulties. Instructional Science, 39(4), 543-559.

Kordaki, M. (2013). High school computing teachers' beliefs and practices: A case study. $\begin{array}{lllll}\text { Computers } & \mathcal{E} & \text { Education } & 68 & \text { (2013) }\end{array}$ https://doi.org/10.1016/j.compedu.2013.04.020 (15.04.2020)

Kubiatko, M., Haláková, Z., Nagyová, S., \& Nagy, T. (2011). Slovak high school students' attitudes toward computers. Interactive Learning Environments, 19(5), 541-547.

Kusumah, W. (2013). Mata Pelajaran Teknologi Informasi dan Komunikasi (TIK) di SD/SMP/SMA dan KKPI di SMK Harus Ada dalam Kurikulum Sekolah = Information and Communication Technology (ICT) Subjects in Elementary/ Junior/ High Schools and KKPI in Vocational Schools Must Be in. Retrieved March 27, 2020, from https://www.change.org/p/mendikbud-m-nuh-jangan-hapusmatpel-tik-kkpi-di-kurikulum-2013-mata-pelajaran-teknologi-informasi-dankomunikasi-tik-di-sd-smp-sma-dan-kkpi-di-smk-harus-ada-dalam-kurikulum$\underline{\text { sekolah }}$

Lavy, V. (2007). Using performance-based pay to improve the quality of teachers. The future of children, 87-109.

Ljubojevic, M., Vaskovic, V., Stankovic, S., \& Vaskovic, J. (2014). Using supplementary video in multimedia instruction as a teaching tool to increase efficiency of learning and quality of experience. International Review of Research in Open and Distributed Learning, 15(3), 275-291.

Lortie, D. 1975. Schoolteacher: A Sociological Study. London: University of Chicago Press.

Loewenberg Ball, D., Thames, M. H., \& Phelps, G. (2008). Content knowledge for teaching: What makes it special?. Journal of teacher education, 59(5), 389-407.

Lubin, I. A. (2016). Intentional ICT: Curriculum, Education and Development. IBE Working Papers on Curriculum Issues No. 17. In UNESCO International Bureau of Education. Retrieved from https://eric.ed.gov/?q=ICT+education\&ff1=dtySince $2014 \& f f 2=$ subTechnology $+\mathrm{U}$ $\underline{\text { ses+in+Education\&id=ED573610 }}$ 
Lye, S. Y., \& Koh, J. H. L. (2014). Review on teaching and learning of computational thinking through programming: What is next for K-12?. Computers in Human Behavior, 41, 51-61.

MacBeath, J. (2012). Future of teaching profession. Brussels: Education International.

Mahjebeen, J. (2017). Women's Vulnerabilities, Women's Voices: Narratives on Patriarchies and Domestic Violence in Assam. ANTYAJAA: Indian Journal of Women and Social Change, 2(2), 166-179.

Martín, A. G., \& Tyner, K. (2012). Media education, media literacy and digital competence. Comunicar: Revista Científica de Comunicación y Educación, 19(38), 3139.

Matewos, A. M., Marsh, J. A., McKibben, S., Sinatra, G. M., Le, Q. T., \& Polikoff, M. S. (2019). Teacher learning from supplementary curricular materials: Shifting instructional roles. Teaching and Teacher Education, 83, 212-224.

Mays, N., \& Pope, C. (2020). Quality in qualitative research. Qualitative research in health care, 211-233.

McGuffee, J. W. (2000). Defining computer science. ACM SIGCSE Bulletin, 32(2), 74-76.

Meho, L. I. (2006). E-mail interviewing in qualitative research: A methodological discussion. Journal of the American society for information science and technology, 57(10), 1284-1295.

Meirink, J. A., Meijer, P. C., Verloop, N., \& Bergen, T. C. (2009). Understanding teacher learning in secondary education: The relations of teacher activities to changed beliefs about teaching and learning. Teaching and teacher education, 25(1), 89-100.

Metcalfe, A., \& Game, A. (2006). The teacher's enthusiasm. The Australian educational researcher, 33(3), 91-106.

Ministry of Education. (2017). Instructions for teaching Informatics in Gymnasium for school year 2017 - 2018. [Odigies gia ti didaskalia tis Pliroforikis sto Gimnasio gia to schol. etos 2017 - 2018]. in Greek. Athens: Ministry Of Education.

Ministry of Education. (2016). Teaching guides and elementary school curriculum 201617 for the learning objective Information and Communication Technologies. [Odigies didaskalias kai didaktea ili Dimotikou Sxoliou 2016-17 gia to didaktiko mathisiako antikimeno Technologies Pliroforias kai Epikinonion]. in Greek. Athens: Ministry Of Education.

Ministry of Education. (2014a). Curriculum of the course "Introduction to the Principles of Computer Science" 2nd grade of General Lyceum and Vocational High School. [Programma Spoudon tou mathimatos "Isagogo stis arches tis epistimis ton I/I" B' taksis Genikou Likiou kai Epaggelmatikou Likiou]. in Greek. Athens: State Printing

Ministry of Education. (2014b). Curriculum of the course "Informatics' Applications" 1st grade of General Lyceum. [Programma Spoudon tou mathimatos "Efarmoges Pliroforikis" A' taksis Genikou Lukiou]. in Greek. Athens: State Printing 
Ministry of Education. (2003). Interdisciplinary Single Curriculum Framework (I.S.C.F) of Informatics. [Diathematiko Enieo Plaisio Programmaos Spoudon (D.E.P.P.S)]. in Greek. Athens: State Printing

Ministry of Education. (1997). Single Curriculum Framework (S.C.F) of Informatics. [Enieo Plaisio Programmaos Spoudon (E.P.P.S)]. in Greek. Athens: State Printing

Ministry of Education and Culture of the Republic of Indonesia. (2019). Pedoman Implementasi Muatan/Mata Pelajaran Informatika Kurikulum 2013 = Guidelines for Implementation of Content / Subjects for Information Curriculum 2013. In Kementerian Pendidikan Dan Kebudayaan. Jakarta.

Mpratitsis, Th. (2013). Informatics in Greek School: Trends, approaches, perspectives. Science and Technology. [I Pliroforiki sto Elliniko Scholio: Tasis, proseggisis, prooptikes]. in Greek. Science and Technology Issues in Education, 6(3), 111-115.

Mpratitsis, Th., Chasanisis, D., \& Chatzopoulos, A. (2012). Teachers' views on the placement of Informatics in elementary schools with extended hours. [Apopsis ekpedeftikon gia ti thesi tis Pliroforikis sta dimotika sxolia dieurimenou orariou]. in Greek. Paper presented at the 6o Panhellenic Conference on "Informatics Didactic", Florina. https://didinfo2012.web.uowm.gr/32-341-350.pdf (01.04.2020)

Muijs, D., \& Reynolds, D. (2017). Effective teaching: Evidence and practice. Sage.

Ndirangu, E. (2008). A Dream Come True. In becoming a teacher in the developing world, Bashiruddin, A., \& Retallick, J. (Eds.), Chapter 8, pp. 90-97. Karachi: Aga Khan University, Institute for Educational Development. Available at: http://ecommons.aku.edu/books/6 (12.042020)

Ng, T. W. H., \& Feldman, D. C. (2009). How broadly does education contribute to job performance? Personnel Psychology, 62(1), 89-134. https://doi.org/10.1111/j.17446570.2008.01130.x

O'Connor, H., Madge, C., Shaw, R., \& Wellens, J. (2008). Internet-based interviewing. The Sage handbook of online research methods.

Osborne, J., \& Hennessy, S. (2003). Literature review in science education and the role of ICT: Promise, problems and future directions.

Palmer, D. (2006). Durability of changes in self-efficacy of preservice primary teachers. International Journal of science education, 28(6), 655-671.

Paraskevopoulou-Kollia, E.-A. (2019). Methodology of qualitative research: interviews and online interviews. Open Education - The Journal for Open and Distance Education and Educational Technology. Volume 15, Number 2, 2019 Section one (C) Open Education. doi:https://doi.org/10.12681/jode.20634

Paraskevopoulou-Kollia, E.-A., Soursou, G., Zogopoulos, B., Oreopoulou, E., Kontou, P., \& Zoura, V. (2018). Computer Science Students' Views on Educational StudiesPedagogy. Journal of Educational Technology, 15(1), 40-52.

Paraskevopoulou-Kollia, E.-A. (2015). Computer Science, ICT, Teaching and Learning Theories. [Pliroforiki, TPE, Didaktiki kai Theories Mathisis]. In Greek. Educational Sciences, 2, 22-37. 
Parker, L. D., \& Northcott, D. (2016). Qualitative generalising in accounting research: concepts and strategies. Accounting, Auditing \& Accountability Journal.

Passey, D. Computer science (CS) in the compulsory education curriculum: Implications for future research. Educ Inf Technol 22, 421-443 (2017). https://doi.org/10.1007/s10639-016-9475-z (12.04.2020)

Patton, B. A., \& Lesage, T. (2010). Are you a dream come true or a nightmare? Desired characteristics in the face to face and online instructor. Turkish Online Journal of Distance Education, 11(4), 193-200

Pavlyshyn, L., Voronkova, O., Yakutina, M., \& Tesleva, E. (2019). Ethical Problems Concernig Dialectic Interaction of Culture and Civilization. Journal of Social Studies Education Research, 10(3), 236-248.

Plati, D., Mpellou, I., \& Mikropoulos, A. (2012). Preparing the future teacher for the digital school. [Proetimazontas ton mellontiko daskalo gia to psifiako sxolio]. Paper presented at the 6o Panhellenic Conference on "Informatics Didactic", Florina

Poggi, I., \& Germani, M. (2003). Emotions at work. International Conference on Human Aspects of Advanced Manufacturing: Agility and Hybrid Automation, 27-30 May 2003, 461-468.

Retrieved

from

http://host.uniroma3.it/docenti/poggi/cursitopdf/emotionatwork.pdf

Potter, J., \& Hepburn, A. (2005). Qualitative interviews in psychology: Problems and possibilities. Qualitative research in Psychology, 2(4), 281-307.

Price, H. E., \& Weatherby, K. (2018). The global teaching profession: how treating teachers as knowledge workers improves the esteem of the teaching profession. School Effectiveness and School Improvement, 29(1), 113-149.

Pyrgiotakis, I. (1992). Greek teachers: empirical approach of their working conditions. [Oi Ellines daskaloi: empeiriki proseggisi ton synthikon ergasias tous]. Athens: Grigoris.

Ratislavová, K., \& Ratislav, J. (2014). Asynchronous email interview as a qualitative research method in the humanities. Human Affairs, 24(4), 452-460.

Resnick, M. (2002). Rethinking learning in the digital age. In Kirkman, G., Cornelius, P., Sachs, J., \& Schwab, K. (Eds.) The global information technology report 2001-2002. New York: Oxford, 4, chapter 3, pp. 32-37.

Rey, O., \& Gaussel, M. (2016). The conditions for the successful use of research results by teachers: reflections on some innovations in France. European Journal of Teacher Education, 39(5), 577-587.

Roland, A., Shiman, P., \& Aspray, W. (2002). Strategic computing: DARPA and the quest for machine intelligence, 1983-1993. MIT Press.

Roth, G., Assor, A., Kanat-Maymon, Y., \& Kaplan, H. (2007). Autonomous motivation for teaching: how self-determined teaching may lead to self-determined learning. Journal of educational psychology, 99(4), 761.

Skaalvik, E. M., \& Skaalvik, S. (2015). Job Satisfaction, Stress and Coping Strategies in the Teaching Profession-What Do Teachers Say?. International education studies, 8(3), 181-192. 
Smith, B. (2018). Generalizability in qualitative research: Misunderstandings, opportunities and recommendations for the sport and exercise sciences. Qualitative research in sport, exercise and health, 10(1), 137-149.

Sonia, G. (Ed.). (2017). Educational research and innovation pedagogical knowledge and the changing nature of the teaching profession. OECD Publishing.

Sorokin, P. (2017). Social and cultural dynamics: A study of change in major systems of art, truth, ethics, law and social relationships. Routledge.

The Educational \& Training Foundation. (2014). Self-development using the 2014 Professional Standards. Retrieved from https://www.et-foundation.co.uk/wpcontent/uploads/2015/06/5399-Self-Development-Prof-Standards 4.pdf

Valeeva, R. A., \& Gafurov, I. R. (2017). Initial teacher education in Russia: connecting theory, practice and research. European Journal of Teacher Education, 40(3), 342-360.

Vanderlinde, R., \& van Braak.Johan, J. (2011). A new ICT curriculum for primary education in Flanders: Defining and predicting teachers' perceptions of innovation attributes. Educational Technology and Society, 14(2), 124-135.

Van Veen, K., \& Sleegers, P. (2006). How does it feel? Teachers' emotions in a context of change. Journal of Curriculum studies, 38(1), 85-111.

Wang, S. K., Hsu, H. Y., Campbell, T., Coster, D. C., \& Longhurst, M. (2014). An investigation of middle school science teachers and students use of technology inside and outside of classrooms: considering whether digital natives are more technology savvy than their teachers. Educational Technology Research and Development, 62(6), 637-662.

Webb, M., Davis, N., Bell, T., Katz, Y. J., Reynolds, N., Chambers, D. P., \& Sysło, M. M. (2017). Computer science in K-12 school curricula of the 21st century: Why, what and when?. Education and Information Technologies, 22(2), 445-468.

Webb, R. (Ed.). (2006). Changing teaching and learning in the primary school. McGraw-Hill Education (UK).

Wenström, S., Uusiautti, S., \& Määttä, K. (2018). "The force that keeps you going": Enthusiasm in vocational education and training (VET) teachers' work. International Journal for Research in Vocational Education and Training (IJRVET), 5(4), 244-263.

Williams, M. (2000). Interpretivism and generalisation. Sociology, 34(2), 209-224.

Zadiropoulou, A. (2016). ICT regarding Greek and Britannic school education, a comparative view. [I technologies tis pliroforias ke epikinonias sti scholiki ekpedeysi tis Elladas ke tis Vretannias, mia sygkritiki theorisi]. $5^{\text {th }}$ International Conference on in Open \& Distance Learning - November 2009, Athens, Greece Proceedings, 5(2A), 181-194.).

Zins, C. (2007). Conceptions of information science. Journal of the American Society for Information Science and Technology, 58(3), 335-350.

https://cs.stanford.edu/about/department-overview (09.04.2020). https://www.cis.upenn.edu/history/ (09.04.2020) 
http://www.research.lancs.ac.uk/portal/en/publications/computer-science-cs-or-

information-and-communication-technologies-ict(0480a0e3-edc1-4b72-a2da-

244f2a31d883).html (09.04.2020).

https://web.csulb.edu/ murdock/histofcs.html (08.04.2020). 
Author(s) will retain the copyright of their published articles agreeing that a Creative Commons Attribution 4.0 International License (CC BY 4.0) terms will be applied to their work. Under the terms of this license, no permission is required from the author(s) or publisher for members of the community to copy, distribute, transmit or adapt the article content, providing a proper, prominent and unambiguous attribution to the authors in a manner that makes clear that the materials are being reused under permission of a Creative Commons License. Views, opinions and conclusions expressed in this research article are views, opinions and conclusions of the author(s). Open Access Publishing Group and European Journal of Education Studies shall not be responsible or answerable for any loss, damage or liability caused in relation to/arising out of conflicts of interest, copyright violations and inappropriate or inaccurate use of any kind content related or integrated into the research work. All the published works are meeting the Open Access Publishing requirements and can be freely accessed, shared, modified, distributed and used in educational, commercial and non-commercial purposes under a Creative Commons Attribution 4.0 International License (CC BY 4.0). 